\title{
TEMPERATURE MEASUREMENTS \\ IN THE DETONATION CHAMBER SUPPLIED BY AIR FROM CENTRIFUGAL COMPRESSOR AND GASEOUS HYDROGEN
}

\author{
JAN KINDRACKI \\ Institute of Heat Engineering, Faculty of Power and Aeronautical Engineering, Warsaw University of Technology, \\ Nowowiejska 21/25, 00-665 Warsaw \\ jkind@itc.pw.edu.pl
}

\begin{abstract}
In this paper, the experimental results of a detonation chamber fed by air from a centrifugal compressor are presented. The detonation chamber was equipped with many different sensors, mostly thermocouples, which were placed in 11 different positions. The distribution of temperature changes along the chamber and radial temperature profile at the outlet are provided. The results here confirm the existence of high mixture stratification. Such mixture stratifications and temperature profiles may be used as an additional chamber wall cooling method. The experiments performed, address key issues regarding the chamber choking problem caused by turbines. The relationship between the turbine performance and detonation chamber are crucial for proper control of turbine jet engine.
\end{abstract}

Keywords: rotating detonation, RDE engine, temperature measurements.

\section{INTRODUCTION}

The phenomenon of gas detonation, was theoretically described independently for the first time by Chapman [1] and Jouget [2] more than a century ago, but has become increasingly attractive in recent years due to its applicability in aerospace engines. Despite the Nichols design of the detonation combustion engine [3] at the end of the 1950's, it's only in the last 20-30 years that interest in the application of the engine has increased. In the simplest case, such engines are characterized by, a small number of parts and lack of rotating elements- Furthermore, due to the fact that the detonation wave propagates at a supersonic velocity with respect to the fresh mixture, the chemical reaction takes place in quasi-isochoric conditions. For the same mixture initial conditions, the thermal efficiency of the detonation process compared to the isobaric 
combustion [4] occurring in all jet engines will be higher. Detonation combustion also has additional advantages over deflagration: an increase of pressure and density behind the detonation wave and the possibility of reducing nitrogen oxide emissions. The former may result in a decreased number of compressor stages, adding to the simplification of the engine, where the need to reduce nitrogen oxide emissions is important due to its harmful nature in the application of air-breathing engines. Such emissions are reduced due to a stable detonation process for very lean fuel-air mixtures. Use of combustion of lean mixtures significantly decreases the combustion temperature and consequently nitrogen oxides emission because main $\mathrm{NO}_{\mathrm{x}}$ formation mechanism is related to the high temperature of the process.

Based on the detonation process, two main types of detonation engines may be realized. The first of these, (historically widely studied) the Pulsed Detonation Engine (PDE), is based on a pulsating detonation in a chamber. The PDE chamber design is simple; a long tube is closed at one end by a fresh mixture feeding system, while the second end is open. The simple spark plug with controller is used as an initiation system. The tube is filled with a fresh, combustible mixture and after initiation by spark plug the combustion zone moves firstly as a deflagration wave, followed by a DDT process, which occurs as a detonation. The exhaust gases move towards the outlet of the chamber, generating a thrust force. This process is repeated with some frequency, which are depends on the length of the tube, type of mixture, initial thermodynamics conditions, etc. The main disadvantages of this solution are thrust pulsation and the need for a relatively long tube. To prevent thrust pulsation and low work frequency, the multitube design with shifted tube initiation time was used [5]. Reducing the length of the engine is associated with an improvement (decrease) of DDT distance for a given mixture [5].

The second kind of detonation engine is a Rotating Detonation Engine (RDE). Here the detonation wave propagates along a circumference with an approximate length equal to the distance from the injection plate. The injection of both components of the mixture is continuous, so the detonation wave propagates as long as a fresh mixture is supplied. The initiation process occurs only once at the beginning of the process. This can be compared to the PDE, where initiation must occur each cycle. A mentioned, the detonation wave propagates in one plane, so that the length of the engine can be made very short and its minimum length to diameter chamber ratio takes a value of roughly 0.3 [4]. The short chamber allows for a significant reduction in the weight and cost of it's manufacturing.

The results shown below refer to the operation of the RDE engine chamber, fed by air from a centrifugal compressor, (compression ratio below 3 ) where generated exhaust gases were used to drive the turbine. In the available literature, there are only few results where temperature measurements for detonation chambers or tubes were performed. Rashed et al. [6] investigated the engine where the combustion chamber was built based on 8 PDE tubes. In their studies, they used an ethylene-air stoichiometric mixture with an average mass flow rate of $3.628 \mathrm{~kg} / \mathrm{s}$. Exemplary test lasting at least $300 \mathrm{~s}$ and generating up to $257 \mathrm{~kW}$ mechanical power. Rasheed et al. [7], describe the temperature measurement at the turbine inlet at several locations using a K-type thermocouple for two different test bench configurations of 75 and $150 \mathrm{~kW}$ turbine power, corresponding to two different rotational speeds of the turbine: 12000 and $15600 \mathrm{rpm}$. In both cases the mean 
temperatures were about $600 \mathrm{~K}$. In addition, the authors performed calculations of gas temperatures based on measurements of the amount of oxygen and carbon dioxide in the turbine exhaust gases and next compared temperature measurements. Both methods were used to determine the turbine performance. Xiaofeng et al. [8] presented the results of a study for a commercial turbocharger and detonation chamber as a single PDE tube fed by a gasoline-air mixture. They presented only a pressure courses, since temperature measurements inside the tube were not performed. Similar results are published by Router et al. [9] for measurements of a single-tube PDE based on the Garetta GT28 turbocharger fed by a lean hydrogen-air mixture. They compared the deflagration and detonation processes and showed a $70 \%$ of increase in specific work of the engine for a lean mixture with an equivalence ratio of 0.64 and a working frequency of $15 \mathrm{~Hz}$. However, here to, temperature measurements were not performed in these experiments. Panicker et al. [10] presented research for a single PDE tube fed by a propane-oxygen mixture. The PDE tube fed the turbine which fed centrifugal compressor (BorgWarner Turbo Systems, model K03) and an additional electrical generator. The authors measured the temperature at one point at the turbine outlet using a $\mathrm{K}$-type thermocouple. The obtained value was $800^{\circ} \mathrm{C}$.

This brief overview shows how temperature measurements in the detonation chambers are difficult to obtain. As a result, there is a lack of temperature data in scientific literature. This paper describes such temperature measurements at a few points inside the detonation chamber.

\section{THE SETUP OF RESEARCH STAND}

The research stand consists of three main parts: the detonation chamber, centrifugal compressor and the turbine. The compressor and turbine were, built from a car turbocharger (model K26). To provide proper flow prior to entering the compressor, a particular inlet with a Prandtl probe and static temperature sensor were designed. Also in the compressor inlet a laser sensor for speed of shaft rotation measurement was attached. The turbine was fed by cold, pressurized air from an external source which drove the compressor to a desired speed. In most experiments this speed was close to $100000 \mathrm{rpm}$. The detonation chamber was made from aluminum alloy PA6 (2017A) with an air inlet, in the shape of a slit, whose width can be easily suited to experiment conditions. The fuel was supplied by some number of holes depending on the choice of mixture composition. Typically the number of holes ranged from 40 to 90 and diameter $0.5-0.9 \mathrm{~mm}$. By varying the air injection slit, the number and diameter of fuel injection holes, the different global equivalence mixture ratio could be easily obtained. Additionally, in the detonation chamber outer wall, at some distance from the injection plate, some selected number of additional air holes was placed. These holes were used only in experiments where the influence of additional cooling of the exhaust gas was investigated. The chamber was equipped with several slots for different arrangement of pressure sensors. The sensors can be arranged as one line along the chamber or in one plane at different angle positions, however in most longer-duration experiments, only one pressure sensor was used. In the chamber and outlet nozzle, thermocouples at 11 different points were located. A view of the research stand is shown in Fig. 1. 


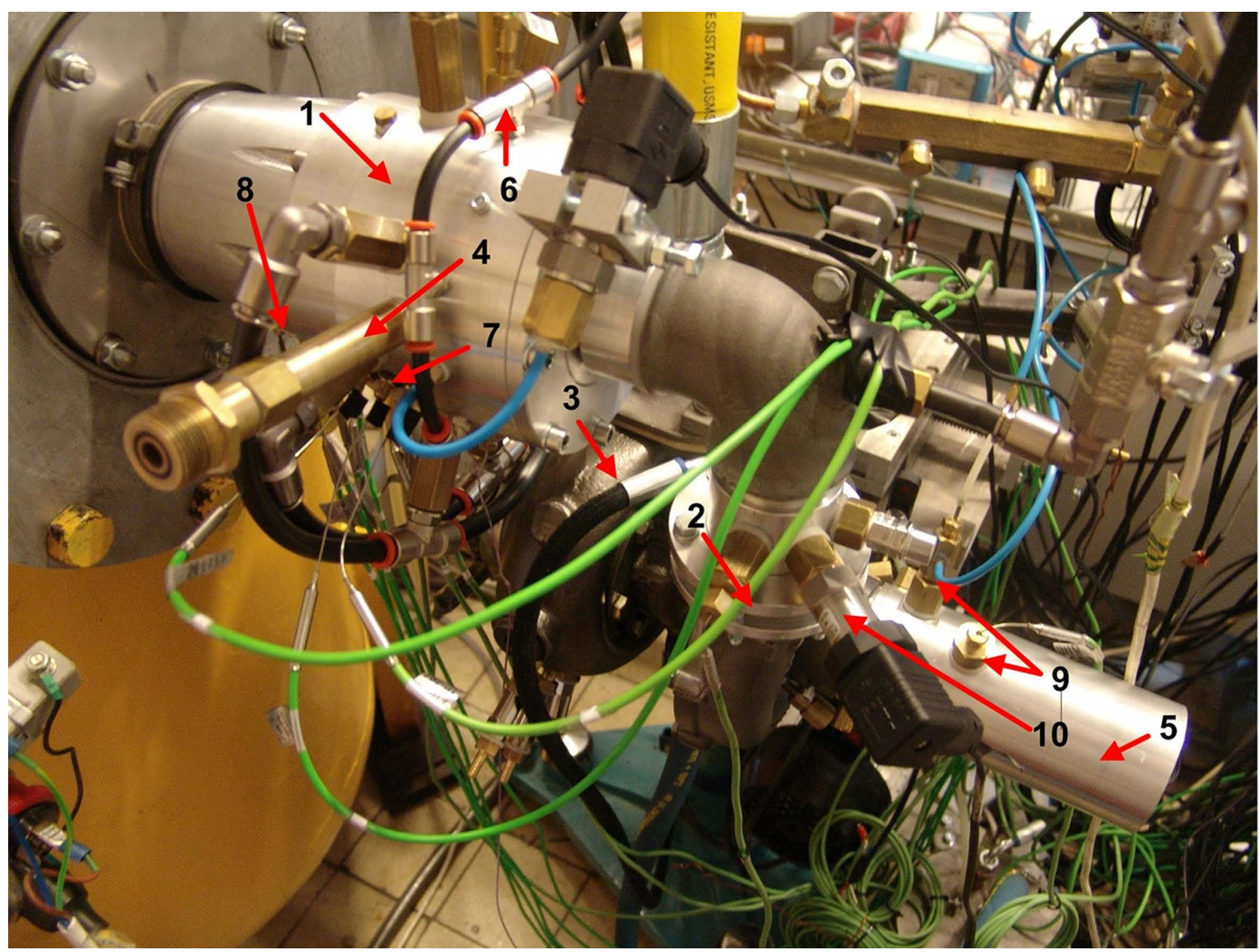

Fig. 1. View of the research stand for the study of the rotating detonation process: 1 - detonation chamber; 2 - centrifugal compressor; 3 - turbine; 4 - initiator; 5 - air intake for the compressor; 6 - fuel supply system; 7 - thermocouples placed inside the chamber; 8 - thermocouples located at the chamber outlet; 9 - Prandtl tube and thermocouple for determining air flow rate; 10 - pressure sensor behind the compressor [Kindracki, 2015]

At this stage of the project, the detonation chamber outflow was connected with a dump tank to suppress the noise and cool the exhaust gases. In the second part of the experiment, one additional element called the "turbine imitator" was used. This element was installed at the outlet of the detonation chamber and simulates choked flow (thermal and hydraulic) caused by the turbine. Additionally, the turbine imitator was able to simulate various degrees of choke, which allowed observation of how the flow changed and how these changes move upstream to the chamber and compressor. The imitator is composed of three discs with holes, representing free flow between turbine blades. The cross-sectional area of turbine blades (called "imitator load") can be compared to the blockage ratio parameter (see $\mathrm{A}_{\text {imitator }} / \mathrm{A}_{\text {full }}$ on Fig.13). The imitator view is shown in Fig. 2.

The measurement system is well developed. It consists of three National Instruments measuring cards: PCI6115, USB 6259 and PCI6133. The first one was used only to measure the pressure inside the detonation chamber with Kistler type 603B transducers and a special 


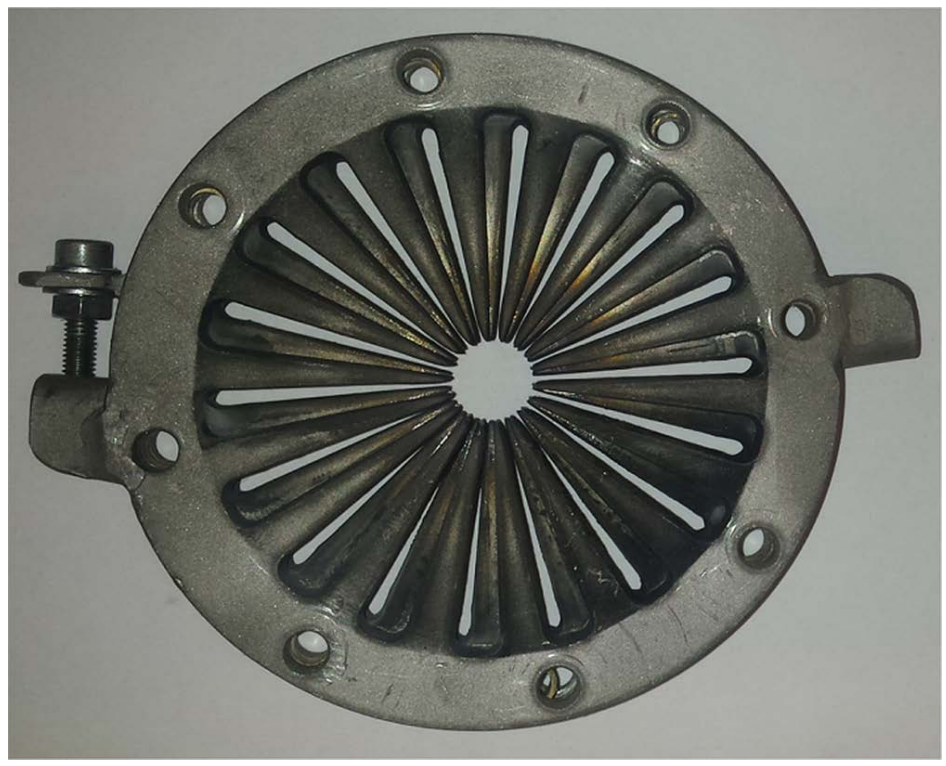

Fig. 2. View of a turbine imitator used in the experimental research [Kindracki, 2015]

microphone with frequency of at least $1 \mathrm{MHz}$ per channel. Additionally, this card controlled every device used in the experiments and synchronized other measurement cards. The second card, USB 6259 is used to measure only the temperature with a frequency $1 \mathrm{kHz}$ per channel. Temperatures on the research stand were measured at 14 different points, providing full information in both manifolds (fuel and air) and the detonation chamber. Five of the thermocouples were located at the outlet in different radial positions to produce the radial profile of the temperature at the outlet. All thermocouples used are K-type made by Czaki Company. The third measurement card was used to collect data from pressure sensors at 7 different point at the inlet and outlet of the compressor and in the fuel manifold. This card also records the signal from the compressor laser speed sensor. Measurements were handled by two computers with dedicated in-house software.

The choice for the use of the K-type thermocouple was dictated by its wide measuring range, linear characteristics above $100^{\circ} \mathrm{C}$ and low price, which was important, considering the high probability of sensor damage during experiments. Due to the short duration of a single experiment, in order to minimize the risk of damage, it was impossible to use the dedicated amplifiers and measurement cards typical during such measurements. Therefore, it was decided to directly measure the electrical voltage generated by thermocouples. Additionally, to obtain correct measurements it was necessary to build a cold-junction compensation system. Special Peltier cell, cooler and PID temperature regulator were used to construct the device. For calculating the temperature from the measured thermoelectric voltage, the temperature-voltage relationships defined in the Polish Standard [11] were used. Fig. 3 shows the measurement scheme and the view of the cold junction compensation device. 


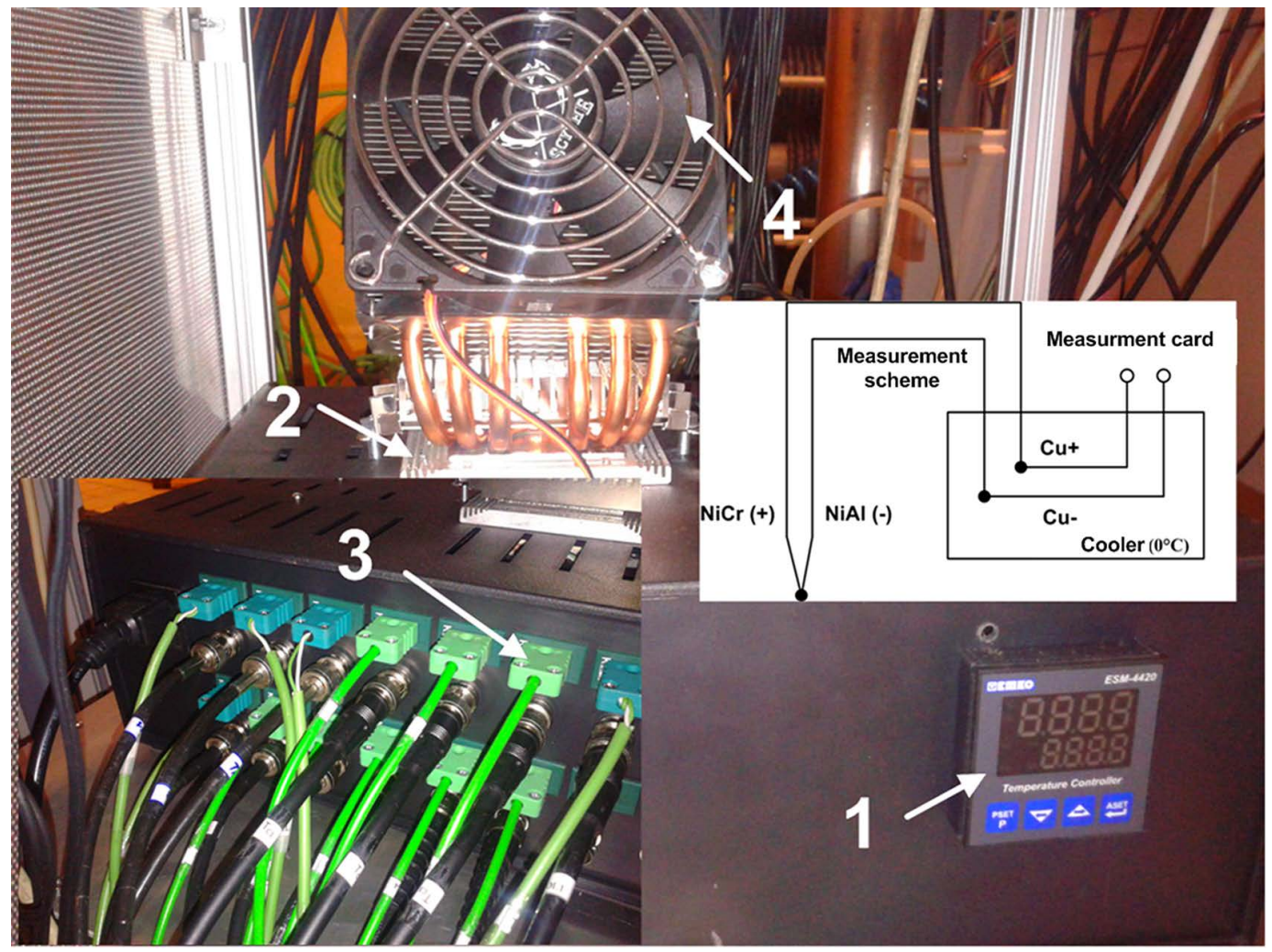

Fig. 3. Scheme of temperature measurement with thermocouples and view of the device for cold junction compensation: 1 - temperature controller, 2 - Peltier cell, heat pipe and cooling heatsink, 3 - thermocouple connections, 4 - cooling fan [Kindracki, 2015].

\section{EXPERIMENTAL RESULTS}

\subsection{An example experiment}

The experimental studies were conducted for a hydrogen-air mixture. The choice of hydrogen as a fuel is motivated for few reasons. The first is the fact that hydrogen is widely recognized as a green fuel with a very high HHV (higher heat value) value. Although its use in aviation systems due to its low density may still be in disagreement, it is still widely used in stationary and ground applications, particularly when used with closely spaced manufacturing facilities. As an example, the future generation of electric power through turbo generators can be recalled. The second reason for the use of hydrogen in laboratory tests is the ease of use in the detonation chamber. The third reason is the relatively low detonation initiation energy of its mixtures with air or oxygen compared to other liquid fuels. The author's experience using hydrogen mixture in experiments was also a deciding factor.

As was mentioned earlier, the hydrogen feed system was very simple and its injection was done through straight, cylindrical holes. The mass flow rate was controlled by one of three factors: number or diameter of holes or injection pressure. Placing the injectors on one inner wall 
resulted in the stratified mixture, where on the inner wall the mixture had stoichiometric or rich composition. On the outer wall the composition was lean and even extremely lean. Changes of the mixture composition depending on the distance from the injectors are described by Kindracki [12]. Such a stratification of the mixture allows for stable combustion of very lean mixtures while reducing the emission of harmful exhaust gases. The air supply to the combustion chamber from the centrifugal compressor was realized by a slot injector and the air parameters could be adjusted by varying the slot width and the compressor speed.

Fig. 4 shows an example course of compressor and fuel line parameters. The red and green lines represent the control signals for the compressor and fuel control valve. In both cases, there is some delay between the time the signal is sent to the system and the time of pressure rise. This is due to the characteristics of the control valves, the compressor and the fuel. Higher compressor delay time also results from the use of a much larger valve and consequently a higher opening delay time. For the hydrogen, delay time was less than $100 \mathrm{~ms}$ and for the compressor about $250 \mathrm{~ms}$. Black and blue curves represent the course of pressure before and behind the compressor, respectively. The opening time of the hydrogen valve (work of the detonation chamber) for the case shown was $500 \mathrm{~ms}$, while the typical experiment length for the temperature measurement case was between 2000 and $3500 \mathrm{~ms}$. Fig. 4 also shows the two different values of the compression ratio generated by the compressor: $\pi_{\mathrm{c} 1}$ and $\pi_{\mathrm{c} 2}$. The first one was calculated during the operation of the compressor when no detonation process occurred in the chamber, the second when a detonation wave propagated in the detonation chamber. An increase in the observed pressure behind the compressor results from the thermal chocking at the outlet of the chamber, which moves upstream to compressor, causing changes in pressure at the compressor outlet, while at the same time decreasing flow velocity through the chamber. On the other hand, the static pressure increase at the compressor inlet comes from the decrease of the inlet velocity, which results in a different relation between the static and dynamic pressure at the compressor inlet.

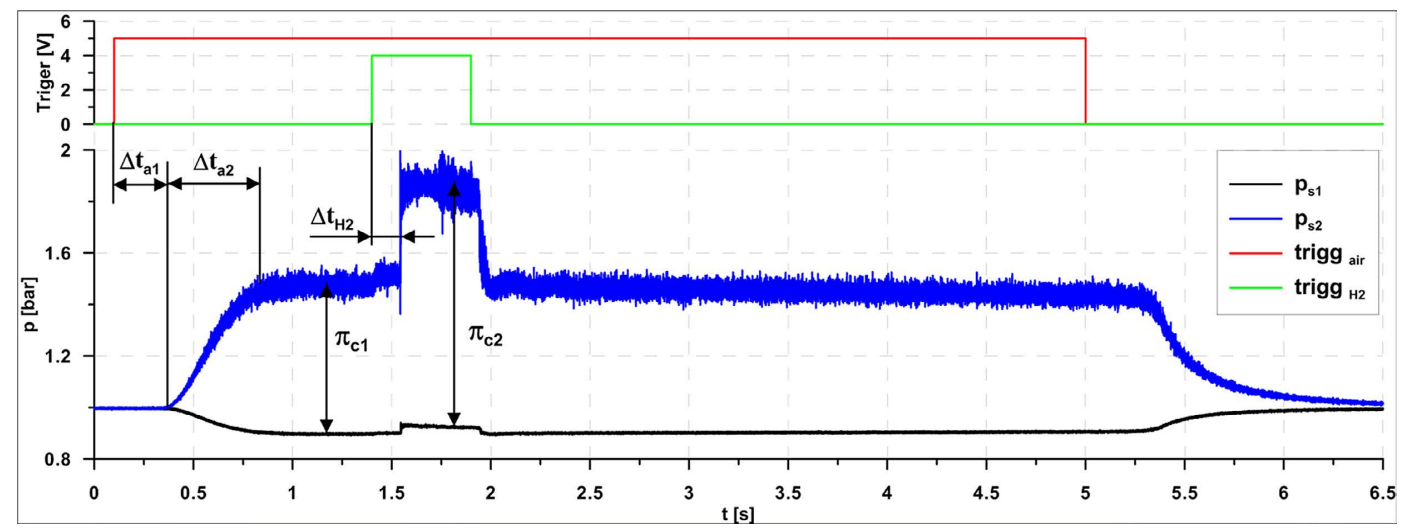

Fig. 4. Pressure distribution for a typical experiment (before and behind the compressor): $\mathrm{p}_{\mathrm{s} 1}$ - static pressure before compressor, $\mathrm{p}_{\mathrm{s} 2}$ - static pressure behind compressor, trigg $\mathrm{air}_{-}$- control signal for compressor, trigg $_{\mathrm{H} 2}-$ control signal for hydrogen valve, $\Delta \mathrm{t}_{\mathrm{a} 1}-$ compressor start delay time, $\Delta \mathrm{t}_{\mathrm{a} 2}-$ compressor starting time, $\Delta \mathrm{t}_{\mathrm{H} 2}$ - hydrogen valve delay time, $\pi_{\mathrm{c} 1}-$ compression ratio before detonation chamber running, $\pi_{\mathrm{cl}}-$ compression ratio during detonation chamber running [Kindracki 2015]. 
Fig. 5 shows the typical pressure distribution in the detonation chamber measured by the Kistler Model 603B sensor. On the right side of this figure, a short time of $2.5 \mathrm{~ms}$ is shown, to better illustrate the pressure waveform. High stability and repeatability can be observed on the above part of this figure. Each single point represents one velocity value calculated between two successive wave passes in front of the sensor. Single pressure peaks mean that the detonation wave passes once above the sensor head. Due to the high temperature behind the detonation wave, the sensor requires some kind of thermal insulation. Head front of the sensor is protected with a special silicone grease layer of thickness from 1 to $3 \mathrm{~mm}$. The protection layer does not have an effect on the results and such a layer may be used in a few future experiments before it becomes unfit for experimental use.

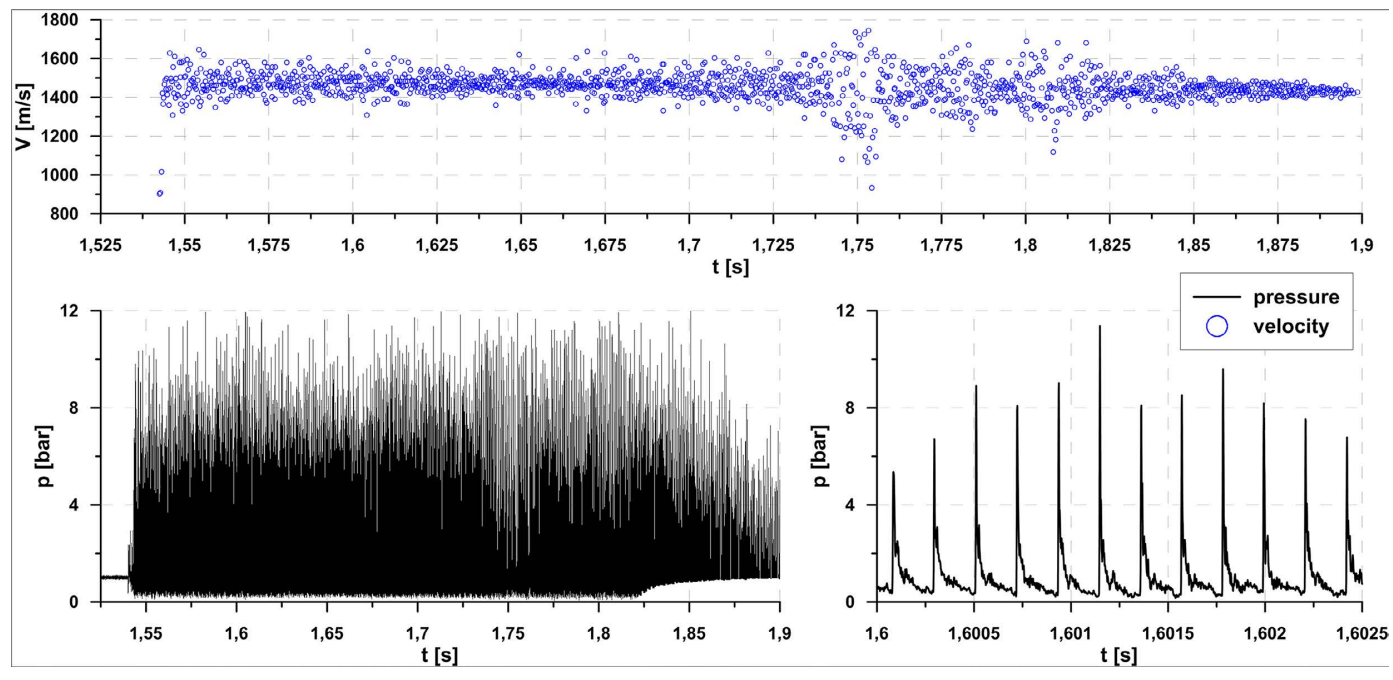

Fig. 5. Typical pressure course and calculated detonation propagation velocity in the detonation chamber [Kindracki, 2015].
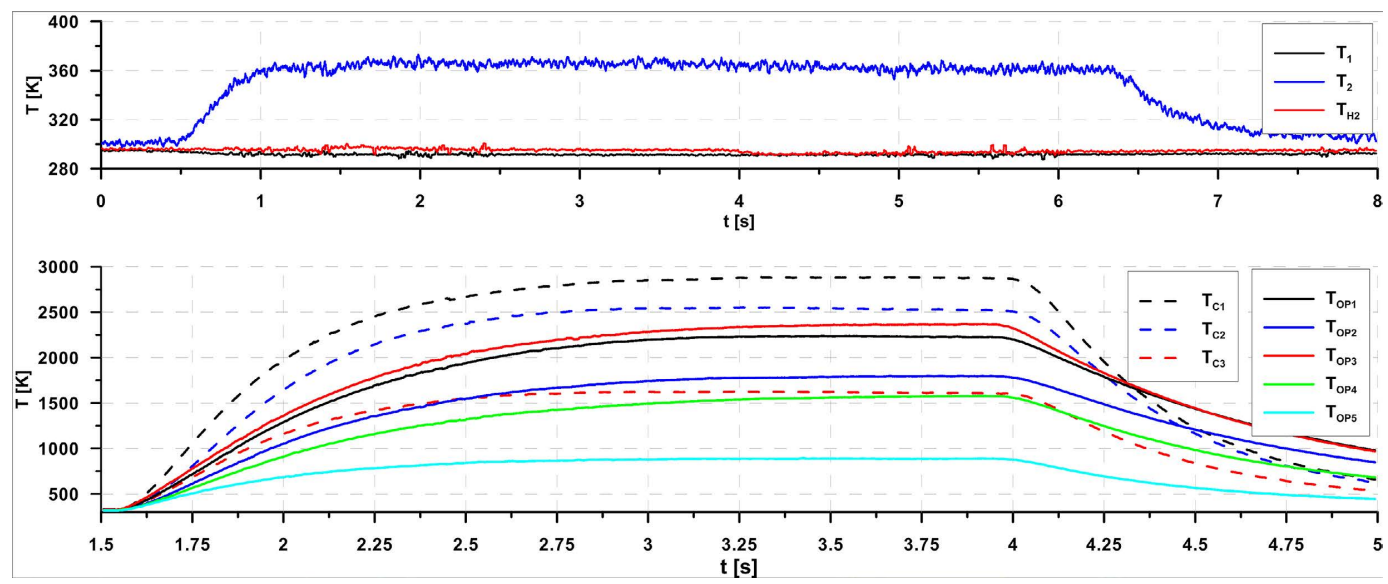

Fig. 6. Typical temperature course at selected positions: in detonation chamber, at its outlet, in the compressor (before and behind) and temperature in fuel manifolds. Total experiment duration time was $3500 \mathrm{~ms}$ [Kindracki, 2015]. 
Fig. 6 shows the typical temperature profile at selected points in the detonation chamber for the duration of the $3500 \mathrm{~ms}$ experiment. The thermocouples show proper values after approximately $1500 \mathrm{~ms}$ from the beginning of the combustion process. It shows that for a correct temperature measurement, the duration of a single experiment is very important, and only for experiments exceeding $2000 \mathrm{~ms}$, can the temperature measurement be deemed correct. Observing the temperature at the chamber outlet, marked $\mathrm{T}_{\mathrm{OP} 1}-\mathrm{T}_{\mathrm{OP} 5}$ a large radial temperature gradient is seen, which is related to the stratified fresh mixture mentioned in previous chapter.

\subsection{Analysis of the results}

As mentioned in the previous chapter, the temperature measurement was carried out in the chamber at 11 points so that it was possible to obtain an accurate wide range of information about the changes inside the chamber and about temperature profiles at its outlet. Fig. 7 shows the location of the thermocouples and Table 1 describes thermocouple arrangement and parameters. Column 4 of this table shows the positions of the individual sensors. The first dimension is a distance from injection plane along the chamber, while the second dimension shows the distance from the outer wall of the chamber (radial positions). The first three thermocouples shown in the table were used to measure the temperature of both fresh components and were placed in the appropriate points at the air and fuel fed lines.

Table 1. Measurement data for the study of the influence of the equivalence ratio on the temperature in the detonation chamber [Kindracki, 2015]

\begin{tabular}{|c|c|c|c|c|}
\hline Lp. & $\begin{array}{c}\text { Thermocouple } \\
\text { description }\end{array}$ & $\begin{array}{c}\text { Thermocouple } \\
\text { number }\end{array}$ & $\begin{array}{c}\text { Sensor placement } \\
\text { (distance from injection } \\
\text { / depth) }[\mathrm{mm}]\end{array}$ & Comments \\
\hline 1 & $\mathrm{~T}_{\mathrm{s} 1}$ & 1 & - & \multirow{2}{*}{$\begin{array}{l}\text { Static temperature before and behind } \\
\text { the compressor }\end{array}$} \\
\hline 2 & $\mathrm{~T}_{\mathrm{s} 2}$ & 2 & - & \\
\hline 3 & $\mathrm{~T}_{\mathrm{H} 2}$ & 3 & - & $\begin{array}{c}\text { Static temperature of injected } \\
\text { hydrogen }\end{array}$ \\
\hline 4 & $\mathrm{~T}_{\mathrm{cl}}$ & 4 & $10.2 \times 4$ & \multirow{6}{*}{ Longitudinal profile of temperature } \\
\hline 5 & $\mathrm{~T}_{\mathrm{c} 2}$ & 5 & $21.7 \times 4$ & \\
\hline 6 & $\mathrm{~T}_{\mathrm{c} 3}$ & 6 & $32.9 \times 4$ & \\
\hline 7 & $\mathrm{~T}_{\mathrm{L} 1}$ & 7 & $68.1 \times 7.5$ & \\
\hline 8 & $\mathrm{~T}_{\mathrm{L} 2}$ & 8 & $88.1 \times 10.5$ & \\
\hline 9 & $\mathrm{~T}_{\mathrm{L} 3}$ & 9 & $108.1 \times 13.3$ & \\
\hline 10 & $\mathrm{~T}_{\mathrm{OP} 1}$ & 10 & $108.1 \times 27.5$ & \multirow{5}{*}{ Radial profile of temperature } \\
\hline 11 & $\mathrm{~T}_{\mathrm{OP} 2}$ & 11 & $108.1 \times 21$ & \\
\hline 12 & $\mathrm{~T}_{\mathrm{OP} 3}$ & 12 & $108.1 \times 15$ & \\
\hline 13 & $\mathrm{~T}_{\mathrm{OP} 4}$ & 13 & $108.1 \times 8$ & \\
\hline 14 & $\mathrm{~T}_{\mathrm{OP} 5}$ & 14 & $108.1 \times 2$ & \\
\hline
\end{tabular}




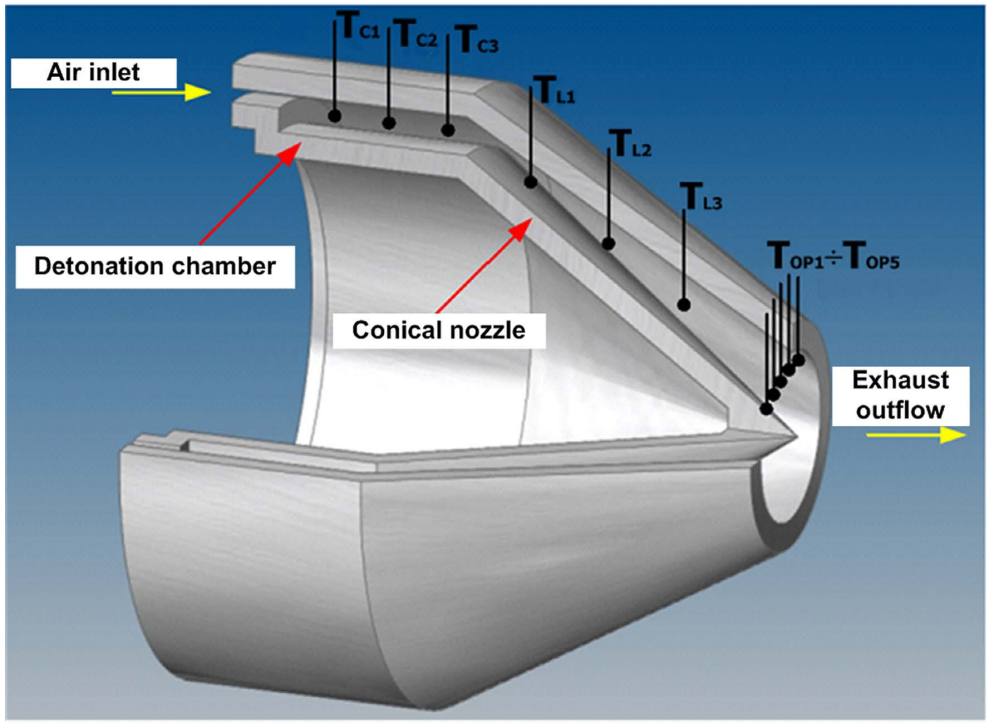

Fig. 7. View of thermocouple placement inside the chamber, conical nozzle and at the outlet [Kindracki, 2015].

Table 2. Measurement data for the study of the influence of the equivalence ratio on the temperature in the detonation chamber [Kindracki, 2016]

\begin{tabular}{|c|c|c|c|c|c|}
\hline $\begin{array}{c}\text { Experiment } \\
\text { number }\end{array}$ & $\pi_{\text {comp }}$ & $\mathrm{m}_{\mathrm{air}}[\mathrm{g} / \mathrm{s}]$ & $\mathrm{p}_{\mathrm{H} 2}[\mathrm{bar}]$ & $\mathrm{m}_{\mathrm{H} 2}[\mathrm{~g} / \mathrm{s}]$ & $\phi$ \\
\hline case 136 & 2.26 & 169.33 & 6 & 2.42 & 0.492 \\
\hline case 137 & 2.25 & 168.61 & 6 & 2.43 & 0.494 \\
\hline case 138 & 2.64 & 195.46 & 6 & 2.41 & 0.424 \\
\hline case 139 & 1.76 & 130.80 & 6 & 2.30 & 0.613 \\
\hline case 140 & 1.75 & 125.93 & 6 & 2.42 & 0.659 \\
\hline case 141 & 2.64 & 197.35 & 6 & 2.41 & 0.419 \\
\hline case 147 & 1.77 & 119.95 & 8 & 3.31 & 0.949 \\
\hline case 148 & 1.77 & 120.11 & 8 & 3.31 & 0.947 \\
\hline case 149 & 2.33 & 167.85 & 8 & 3.32 & 0.680 \\
\hline case 150 & 2.31 & 166.50 & 8 & 3.31 & 0.684 \\
\hline case 151 & 2.68 & 192.59 & 8 & 3.32 & 0.592 \\
\hline case 152 & 2.67 & 192.20 & 8 & 3.33 & 0.595 \\
\hline case 153 & 1.26 & 59.02 & 8 & 3.33 & 2.003 \\
\hline
\end{tabular}




\section{Influence of global mixture equivalence ratio}

Firstly, the effect of the global equivalence ratio on the detonation chamber temperature was investigated. Further measurements were made for constant hydrogen injection pressure and variable rotational speed of the compressor, resulting in a change in compression ratio and mass flow rate. These tests were performed for different hydrogen injection pressures and for this paper only two values of 6 and 8 bar were chosen. Table 2 presents the basic parameters of the experiments: fuel and air mass flow rate, compression ratio and mixture equivalence ratio. The average temperature values shown in following graphs (Fig.8-10) were calculated after stabilizing the temperature profile, using an averaging time length of 200 to $1000 \mathrm{~ms}$, depending on the duration of the experiment.

The next two graphs (Fig. 8 and Fig. 9) show the temperature profiles for the two described hydrogen injection pressures of 6 and 8 bar, varying the rotational speed of the compressor. The graphs show the values for thermocouples no 7-14. Thermocouple number 7 was located in the part of the chamber where the shape changed from toroidal to the conical, while thermocouples number 10-14 were given the radial profile at the outlet of the chamber where the conical part transforms to cylindrical (see Fig. 7). Between thermocouple no 10 and 14 it is observed temperatures may vary $300^{\circ} \mathrm{C}$ or more. This difference confirms that the fresh mixture was stratifying in the chamber. This also shows that the equivalence ratio calculated from the mass flow rate for both gases should be treated as a global coefficient of equivalence ratio. Locally, compositions changed from rich to lean limits of the detonation range. This is also confirmed by numerical calculations of fresh mixture compositions done by authors in other works [12]. This variability of the local equivalence ratio coefficient explains that detonation can propagate, despite the fact that the global equivalence ratio is lower than 0.535 - the lean detonation limit for hydrogen-air mixture [17]. Observations made during experiments shows that detonation can propagate in stratified hydrogen-air mixtures. To better illustrate the temperature change as a function of the equivalence ratio, Fig. 10 shows results for selected thermocouples $T_{10}$. The relation between temperature and the equivalence ratio coefficient is extremely important due to control system and control program of such combustion chamber. Such systems should responds quickly to any changes and maintain a constant temperature at the turbine inlet.

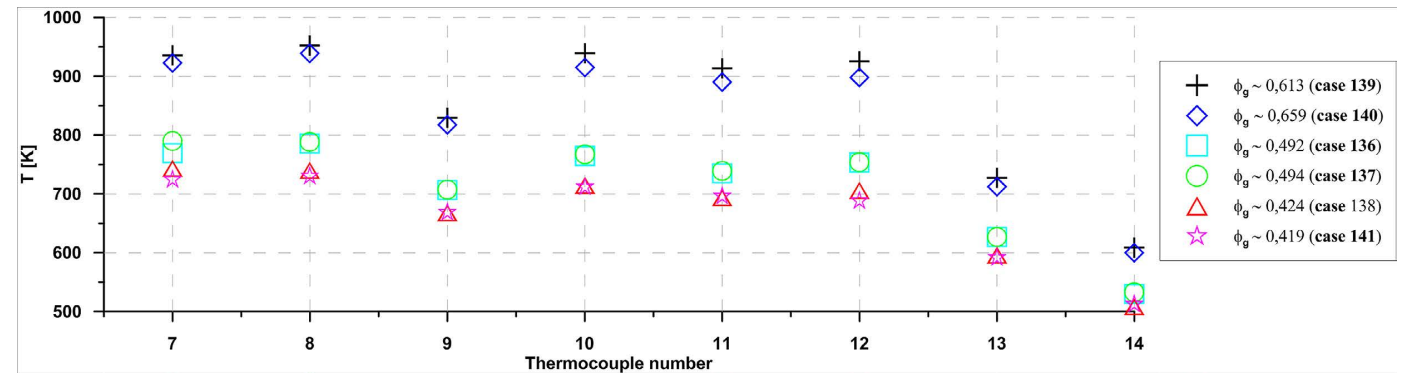

Fig. 8. Average temperature for different thermocouples in the nozzle and at the chamber outlet for different global equivalence coefficient $\phi_{\mathrm{g}}$ without wall and exhaust gases cooling for constant hydrogen injection pressure of 6 bars and variable speed of the compressor [Kindracki, 2016]. 


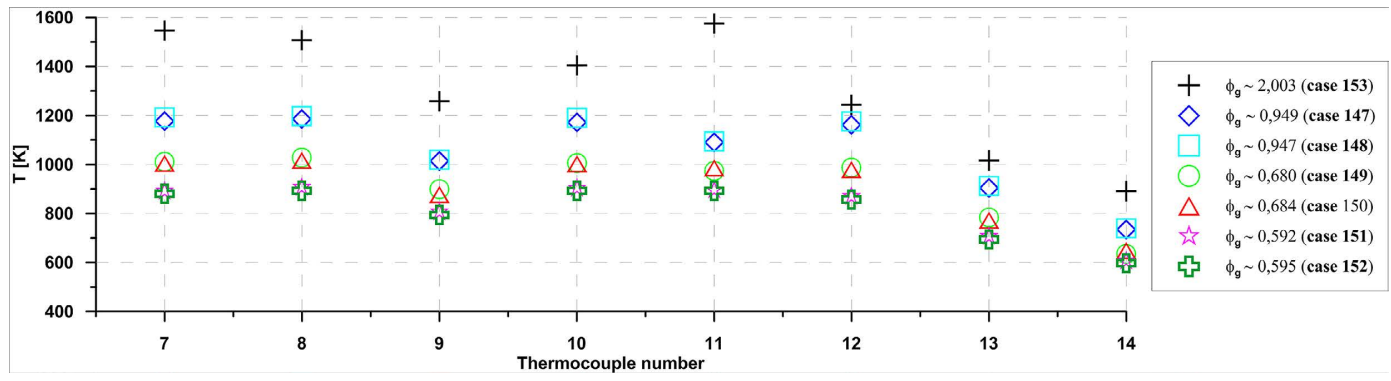

Fig. 9. Average temperature for different thermocouples in the nozzle and at the chamber outlet for different global equivalence coefficient $\phi_{\mathrm{g}}$ without wall and exhaust gases cooling for constant hydrogen injection pressure of 8 bars and variable speed of the compressor [Kindracki, 2016].

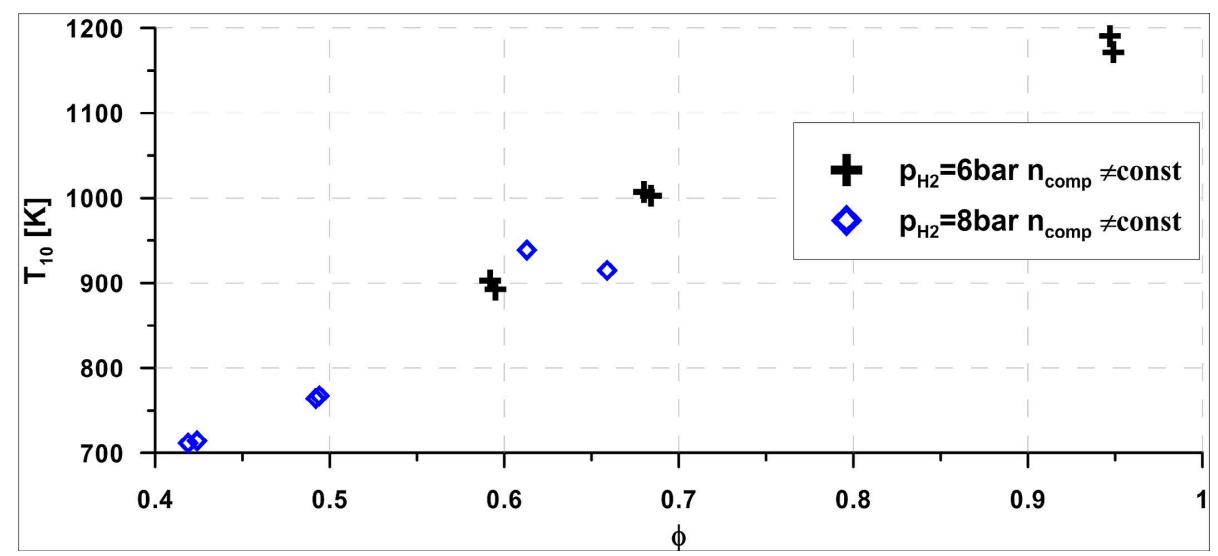

Fig. 10. Influence of the global equivalence ratio on average temperature (thermocouple $\mathrm{T}_{10}$ ) for constant fuel injection pressure and variable compressor speed. [Kindracki, 2016]

\section{Influence of turbine imitator}

As mentioned earlier, one of the reasons for measuring the temperature in a chamber at several points is to obtain information about the temperature field prior to installing such a chamber in real gas turbine engines. Therefore, it was concluded that the influence of turbine choking on the detonation process must be investigated. The description of the turbine imitator was presented in chapter 2. Table 3 shows the data of the turbine imitator experiments for hydrogen injection pressures in the range of 5-6 bar. 
Table 3. Measurement data for the study of the influence of cooling gas and turbine imitator on the temperature in the detonation chamber [Kindracki, 2016]

\begin{tabular}{|c|c|c|c|}
\hline $\begin{array}{c}\text { Experiment } \\
\text { number }\end{array}$ & $\pi_{\text {comp }}$ & $\mathrm{m}_{\text {air }}[\mathrm{g} / \mathrm{s}]$ & $\mathrm{p}_{\mathrm{H} 2}[\mathrm{bar}]$ \\
\hline case 89 & 2.06 & 173.95 & 5.5 \\
\hline case 92 & 2.1 & 172.80 & 5.5 \\
\hline case 93 & 2.08 & 167.35 & 5.5 \\
\hline case 94 & 2.11 & 169.06 & 6 \\
\hline case 96 & 2.17 & 162.70 & 6 \\
\hline case 97 & 2.15 & 160.48 & 6 \\
\hline case 104 & 2.25 & 138.67 & 6 \\
\hline case 105 & 2.27 & 139.44 & 6 \\
\hline case 106 & 2.42 & 94.75 & 6 \\
\hline case 107 & 2.39 & 91.57 & 6 \\
\hline
\end{tabular}

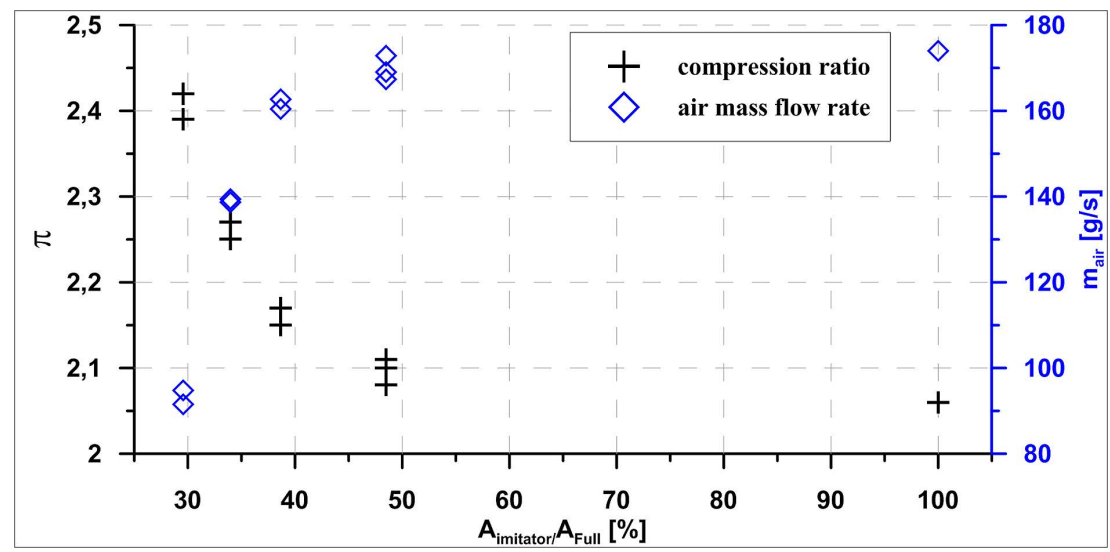

Fig. 11. Influence of percentage of the turbine imitator outlet area (the effect of the change in turbine load) on the compression ratio and mass flow rate [Kindracki, 2016].

As mentioned earlier, the imitator load was defined as the ratio of imitator area $\left(\mathrm{A}_{\text {imitator }}\right)$ to chamber outlet area $\left(\mathrm{A}_{\mathrm{Full}}\right)$. This value could be adjusted continuously from about $48 \%$ to 0 . A value of zero means that flow is completely blocked. By changing the imitator load, was possible to observe the effects of turbine flow choking on detonation chamber performance. Fig. 11 shows 
the compression ratio and mass flow rate as a function of imitator load. Any significant changes observed were due to a reduction in cross-sectional area to approximately $50 \%$ of the full tube area (chamber outlet). However, further reduction of this area resulted in exponential growth of the compression ratio and significant decrease in the mass flow rate. For an imitator load value of about $30 \%$, the compression ratio increased by about $20 \%$, while at the same time, the mass flow rate decreased roughly $50 \%$. For these same fuel injection parameters, air mass flow rate decreases lead to large changes in the mixture composition and hence on the detonation chamber temperature. This means than experimental results from the detonation chamber case cannot be directly applied for the detonation chamber with turbine experiment case. Before the turbine is placed into the flow, careful analysis of non-turbine temperature fields should be done to anticipate what may happen in the presence of a turbine. In the extreme case, the turbine may be destroyed.

Fig. 12 shows the temperature changes for different choking values at the chamber outlet for mixture close to stoichiometric. Compared to the graphs presented earlier, significant increase in temperature for all measuring points is observed. Temperature values for cases 106 and 107 at most measurement points are higher than $2500 \mathrm{~K}$. Measurement of such values with use of the K-type thermocouple may not be fully reliable, as its measurement range defined by manufacturers ends for $1600 \mathrm{~K}$. Additionally, the linear relationship between voltage and temperature remains an open issue. However, such measured data was also shown to better illustrate thermodynamic conditions inside the detonation chamber. On the one hand the experiments were long enough to stabilize the indicated value, and on the other hand were short enough that the thermocouple was not destroyed, so that results may be reliable. Reproducibility of the results was good. It was assumed that for temperature values exceeding the present measuring range, the accuracy was about $\pm 100 \mathrm{~K}$. Measurements for the same initial thermodynamic conditions and mixture compositions were repeated several times to check the repeatability of the measurements. It can be concluded that the chamber temperature rapidly increases, along with rapid decrease of mass flow rate (see Fig. 11), when the turbine imitator total area ratio decreases.

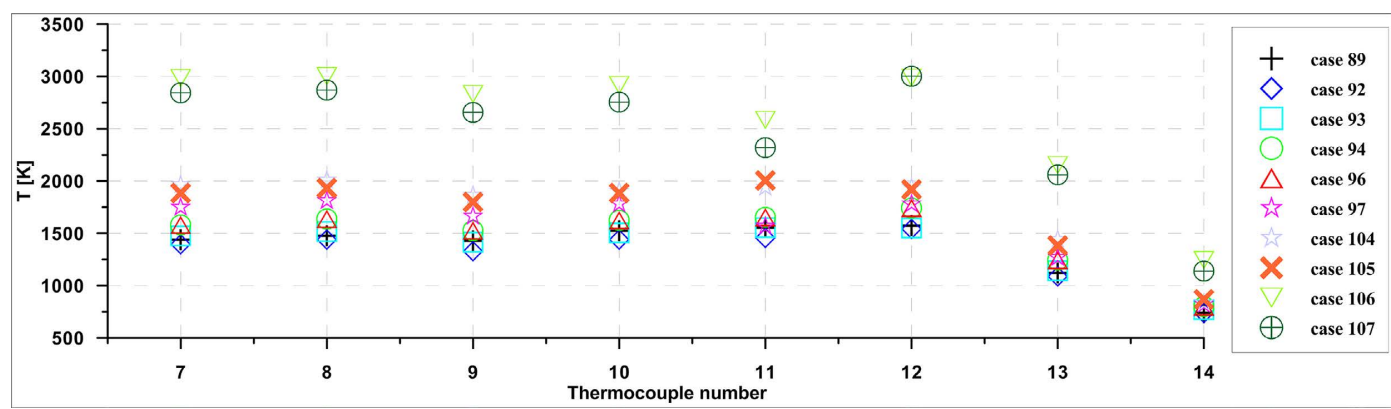

Fig. 12. Average temperatures for different thermocouples as a function of percentage of the turbine imitator outlet area [Kindracki, 2016]. 
A significant rate of temperature change is observed after crossing some limit of area ratio (Fig 13) for a selected thermocouple. The horizontal axis represents area ratio where a value $100 \%$ means that channel is completely open. Using an area ratio up to $50 \%$ has no observable effect on the temperature, but ratios exceeding 50, that when this ratio decreases, the temperature increase first very slowly and next for area ratio close to $35 \%$, temperature groves rapidly. This shows that for such channel choking, the flow rapidly decelerates and mixture compositions change from lean to stoichiometric or even rich.

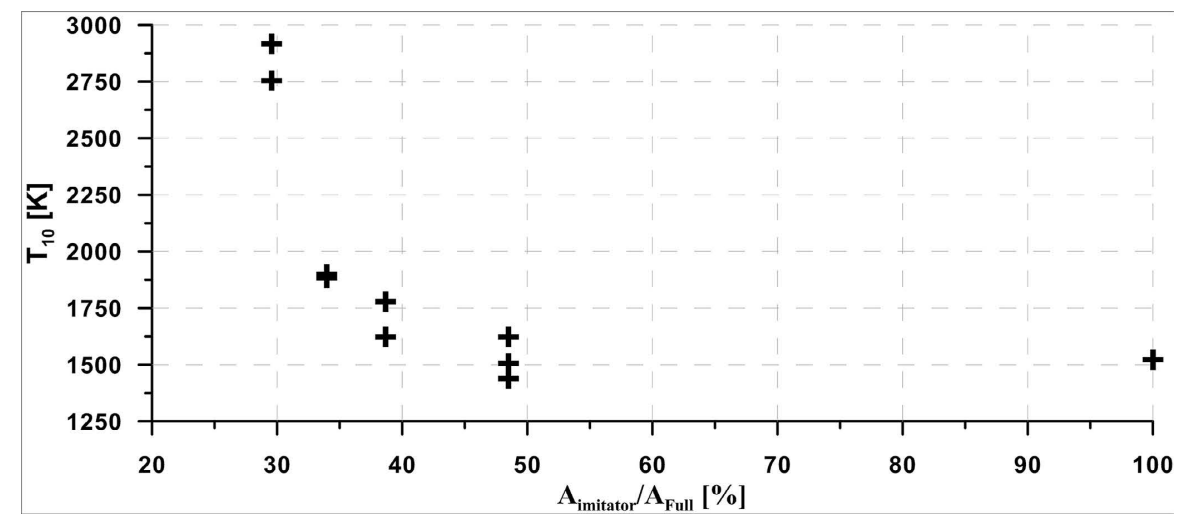

Fig. 13. Influence of the turbine outlet area ratio (turbine load) on the average temperature $T_{10}$ [Kindracki 2016].

\section{SUMMARY AND CONCLUSIONS}

The paper presents experimental results for a detonation chamber fed by air from a centrifugal compressor using gaseous hydrogen. A research test stand equipped with various measuring sensors is described. Analysis of the experimental results lead to the following conclusions:

- Measurements of the temperature in the detonation chamber are difficult and require the use of appropriate sensors and a sufficiently long working time to ensure that the results are reliable;

- With such long-term measurements, sensor protection is extremely important;

- The placement of the gaseous fuel injector is essential for obtaining the desired composition of the mixture in the chamber. Studies have shown great potential for controlling the mixture composition and it's influence on the exhaust gas temperature;

- The proper selection of the mixture composition across the channel can be an important part of the cooling system. The presented temperature measurements show that the distribution of the fresh mixture before the combustion front, behind this still influence on the temperature even in long distance from the injection and mixing area;

- Detonation combustion of stratified mixtures allows for stable propagation of lean mixtures or even for mixtures where the global equivalence mixture ratio is outside the detonation limits;

- For stoichiometric to lean mixtures, the temperature of the gases are an approximately linear function of equivalence ratio; 
- The use of turbine imitators has shown the need to exercise caution when the turbine is placed in the detonation chamber. This is due to the significant influence of the turbine on the process in the detonation chamber and the flow through the compressor. It has been shown that, after exceeding a certain value of the choking coefficient, the compression ratio and the temperature of the exhaust gases grows quickly. This results in the necessity to use special control methods to prevent damage to the turbine elements and/or chamber;

- It has been shown that even when the mass flow rate is reduced by approximately $50 \%$, this does not have a significant influence on the gas temperatures;

- For measurements with a K-type thermocouple, when the measured temperature lie outside the manufacturer's specified range such results carry a lower accuracy.

\section{BIBLIOGRAPHY}

[1] Chapman D. L., 1899, "VI. On the rate of explosion in gases", Philosophical Magazine Series 5, Volume 47, Issue 284, pp.90-104.

[2] Jouguet E., 1905, "Sur la propagation des réactions chimiques dans les gaz" [On the propagation of chemical reactions in gases], Journal de Mathématiques Pures et Appliquées, series 6 (in French) 1: pp. 347-425.

[3] Nicholls J.A., Wilkinson, H.R., and Morrison, R.B., 1957, "Intermittent Detonation as a Thrust Producing Mechanism.”, Jet Propulsion, Vol. 27, pp. 534-541.

[4] Kindracki J., 2008, „Badania eksperymentalne i symulacje numeryczne procesu wirującej detonacji gazowej" [Experimental research and numerical calculation of the rotating detonation], Ph.D. Thesis, Warsaw University of Technology (in polish)

[5] Kailasanath K., 2000, "Review of Propulsion Applications of Detonation Waves", AIAA Journal, Vol. 38, No. 9, pp. 1698-1708, http://dx.doi.org/10.2514/2.1156.

[6] Rasheed A., Furman A., \& Dean A. J., 2005, "Experimental investigations of an axial turbine driven by a multi-tube pulsed detonation combustor system", $41^{\text {st }}$ AIAA/ASME/SAE/ASEE Joint Propulsion Conference, Tucson, AIAA 2005-4209.

[7] Rasheed A., Furman A.H., and Dean A.J., 2011, "Experimental Investigations of the Performance of a Multitube Pulse Detonation Turbine System", Journal of Propulsion and Power, Vol. 27, No. 3, pp. 586-596, DOI: 10.2514/1.B34013.

[8] Xiaofeng L., Longxi Z., Hua Q., Jingbin C., 2013, "Experimental Investigations on the Power Extraction of a Turbine Driven by a Pulse Detonation Combustor", Chinese Journal of Aeronautics Volume 26, Issue 6, pp. 1353-1359, http://dx.doi.org/10.1016/j.cja.2013.07.015.

[9] Router K.P., King P.I., Schauer F.R., Sondergaard R., Hoke J.L., 2010, "Parametric Study of Unsteady Turbine Performance Driven by a Pulse Detonation Combustor", 46 ${ }^{\text {th }}$ AIAA/ ASME/SAE/ASEE Joint Propulsion Conference \& Exhibit, Nashville, AIAA 2010-6536.

[10] Panicker P.K., Li J., and Lu F.K., and Wilson D.R., 2007, “Application of Pulsed Detonation Engine for Electric Power Generation", 45 ${ }^{\text {Th }}$ AIAA Aerospace Sciences Meeting and Exhibit, Reno, AIAA 2007-1246.

[11] Polski Komitet Normalizacyjny, 1997, „Charakterystyka termoelektryczna termoelementów”, Polska Norma PN-EN 60584-1 (in polish). 
[12] Kindracki J., 2014, „Problem pomiaru temperatury w detonacyjnych komorach spalania”, rozdział w monografii: „Termodynamika i wymiana ciepła w badaniach procesów cieplno-przepływowych", pp.211-223 (in polish).

[13] “Alternative Control Techniques Document-NOx Emissions from Stationary Gas Turbines", 1993, U.S. Environmental Protection Agency Office of Air and Radiation Office of Air Quality Planning and Standards Research Triangle Park, EPA-453/R-93-007.

[14] Greenwood S.A, 2000, "Low Emission Combustion Technology For Stationary Gas Turbine Engines", Proceedings of the 29th Turbomachinery Symposium Texas A\&M University, pp.125-133.

[15] Correa S.M., 1991, "Lean premixed combustion for gas-turbines: review and acquired research", In: Ruiz R, editor. Energy-sources technology conference and exhibition, PD-Vol. 33, Fossil Fuel Combustion, Houston, p.1-9.

[16] Bahlmann F.C., Visser B.M., 1994, "Development of a lean-premixed two-stage annular combustor for gas turbine engines", In: ASME 1994 International Gas Turbine and Aeroengine Congress and Exposition, American Society of Mechanical Engineers, pp. V003T06A034.

[17] Kenneth K. K., 2005, “Principles of combustion”, Second edition, John Wiley \& Sons, New Jersey, Chap.4.

\section{POMIARY TEMPERATURY W KOMORZE DETONACYJNEJ ZASILANEJ POWIETRZEM ZE SPRĘŻARKI ODŚRODKOWEJ I GAZOWYM WODOREM}

\section{Streszczenie}

Artykuł przedstawia wyniki eksperymentalne badania komory detonacyjnej zasilanej powietrzem ze sprężarki odśrodkowej. Komora badawcza wyposażona była w liczne czujniki pomiarowe, głównie temperatury, która mierzona była aż w 11 punktach. Dzięki temu możliwe było uzyskanie informacji o zmianach temperatury zachodzących wzdłuż komory a także informację o profilu promieniowym na jej wylocie. Pomiary temperatury potwierdziły istnienie silnego rozwarstwienia mieszaniny w komorze oraz konsekwencji z tego wynikających a także możliwości zastosowania tego faktu, jako uzupełniającą metodę chłodzenia ścianek. Wykonano także badania wpływu dławienia komory poprzez imitator turbiny, co pozwoliło na wyciągnięcie szeregu cennych wniosków przed podłączeniem komory do rzeczywistej turbiny spalinowej. Przeprowadzone badania, a zwłaszcza wyznaczenie temperatury w funkcji współczynnika ekwiwalencji może być bardzo użyteczne przy projektowaniu układu sterowania komorą w sytuacji zainstalowania jej w turbinie spalinowej. Słowa kluczowe: wirująca detonacja, silnik detonacyjny RDE, pomiar temperatury.

\section{Podziękowania/ Acknowledgment}

This work was supported by the National Science Center, Republic of Poland: project no. 838/B/T02/2009/37 and project no. UMO-2012/05/D/ST8/02308. 